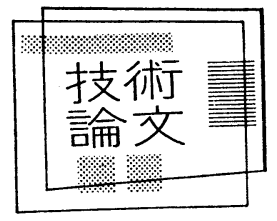

\title{
低周波振動解析器に関する一実験
}

\author{
毛 利 泰 裕**, 葉 山真 治**
}

概 要

一般に舶用機関などで計測される振動の振動数は, 可聴周波数帯（オーディオ周波数帯）の振動数と比較 して非常に低いために，オーディオの周波数分析器のような専用の周波数分析器を使用することができず, ふつうは, データを読み取り数值計算によってフーリエ解析し, 周波数分析を行なう方法がとられている. これは低周波域で帯域幅の狭いバンドパスフィルタを，通常の方法で製作することが非常に困難なためであ る.

そこで, この点を解決する一つの方法として, 帯域消去形の Twin Bridge 回路によって, 増幅器に帰還 をかけたいわゆる能動フィルタを使用して, 低周波の振動解析器を試作してみた. 能動フィルタの中心周波 数は, 電話用セレクタスイッチによって抵抗 $\mathrm{R}$ と容量 $\mathrm{C}$ とを切り換え，1/12オクターブごとに順次移行させ ていく方法を使用し， $1.00 \mathrm{H}_{\mathrm{z}}$ から $241.8 \mathrm{H}_{\mathrm{z}}$ までの周波数範囲を解析の対象とした.

本試作器に, あらかじめ振動数と振幅とがわかっている正弦波を合成して作った入力信号をいれて解析し てみた．また，この信号をペンオシログラフに描かせて，その一周期を読み取り，数值計算でフーリエ解析 したものとも比較してみた，その結果，つぎのことがわかった.

（1） 本試作器は振動数成分については一応正しく解析できた.

（2）振幅については，含まれている成分の比率もほぼ正しく解析しているが，数值計算によるもののほ うがややよい.

（3）しかし, 数值計算で求めたものについては, 読み取り誤差のため, 高調波成分に抒いて大きな誤差 が現われる。

この試作器により, 能動フィルタ方式による低周波振動解析器が実際に使用し得るとの見通しが得られた.

\section{An Experiment on Low Frequency Spectrum Analyser}

\author{
by Yasuhiro Mori, Shinji Hayama
}

\begin{abstract}
The vibrations which are produced in marine engines consist of, in general, very low frequency components, compared with those of audio frequencies. As, in the low frequency band, it is is very difficult to make a narrow band-pass filter by the use of usual inductances, capacitances and resistanses, we can not utilize a suitable frequency spectrum analyser, as used in audio frequency band, and must use tiresome numerical methods in order to analyze the spectra of such vibrations as mentioned above.

As one of the methods to solve this difficulty, an active filter is introduced, which consists of a DC amplifier and its feed-back circuit with the $\mathrm{R}-\mathrm{C}$ twin bridge. By using the active filters, a low frequency spectrum analyser is built, in which the center frequency of the filter is shifted step by step by $1 / 12$ octave autmatically through selector switches and the frequency band is covered from 1 to $241.8 \mathrm{~Hz}$.

The spectrum analyser is tested with the input signals which consist of sinusoidal waves whose frequencies and the ratio of their amplitudes are kown beforehand. The results are also compared with those obtained by Fourier expansion method. The following results are obtained.
\end{abstract}

*原稿受付 昭和44年 4 月 1 日 $\quad * *$ 正会員, 東京大学工学部（東京都文京区本郷 7-3-1） 
The low fequency spectrum analyser built in this experiment can detect almost exactly the frequency components contained in the test signals. The analyser can give the nearly exact ratio of amplitudes of the components 'contained. The numerical results give rather good values. However, the numerical ones give also higher harmonic components which are, in reality, not contained in the test signals. It can be expected that the low frequency spectrum analyserbuilt in this experiment may be used in practice.

\section{1. まえがき}

従来, 舶用機関などで計測される振り振動や架構の 振動のスペクトル解析を行なうには，たとえば，その 波形を電磁オシログラフやペンオシログラフに描かせ て, 機関の一回転分をいくつかに分割して, その值を 読み取りフーリエ解析を行ならか，または，データレ コーダに記録し，テープ速度を数倍から数十倍にあげ て，これを可聴周波数帯（オーディオ周波数帯）のア ナライザ (周波数分析器) にかけて, その振動のスペ クトルを求めるといった方法が用いられてきたようで ある. その理由として, 舶用機関, 特に低速ディーゼ ル機関で問題となる振動の振動数がオーディオの振動 数と比較して非常に低いといらこと，たとえば，120 $\mathrm{rpm}$ で回転している機関の 6 次の高調波, すなわち 6 次の成分を考えたとすれば, $12 \mathrm{H}_{\mathrm{Z}}, 16$ 次のものをみて も，たかだか $32 \mathrm{H}_{\mathrm{Z}}$ であり，低周波数 $\left(0.5 \sim 100 \mathrm{H}_{\mathrm{Z}}\right)$ の振動解析器を通常のバンドパスフィルタ (以下 BPF と略する）を用いて製作することが実用上困難である こと, さらに, その通過帯域の極度に狭いものをも製 作することが困難であるために，オーディオのスペク トルアナライザほど比較的容易に製作できないことな どがあげられる。

そこで, 従来のオーディオアナライザについての原 理を考えてみると, おおむね二通りの方法に分けるこ とができる(1).

（A） BPF を 1 個内蔵し，入力信号を変調などして 一定の周波数として取り出し記録する.

（B）解析に必要な周波数範囲（たとえば，オーデ イオにおいては $20 \mathrm{H}_{\mathrm{Z}} \sim 20 \mathrm{~K} \mathrm{H}$ ）を包括するのに必要 な数のB P Fをそろえる.

したがって，たとえば，通過帯域 $1 / 3$ オクターブの B P F を使用し，上記の周波数範囲を包括するために は, 中心周波数が $20 \mathrm{H}_{\mathrm{z}}$ のB P F を 1 番目のB P F とし， 2 番目には $25 \mathrm{H}_{\mathrm{Z}}, 3$ 番目には $31.5 \mathrm{H}_{\mathrm{Z}}, 4$ 番目 には $40 \mathrm{H}_{\mathrm{Z}}$ ，というように，20K $\mathrm{H}_{\mathrm{Z}}$ まで合計 31 個の B P F が必要である.

これらの方法は互いに長所短所をもっており, どち らがよいかということはいちがいにはいえない.まず （A）について考えてみると，B P F が1個であるため
その通過帯域は入力信号の振動数が高くなるにしたが って分析能力がよくなり，また高価な B P F が 1 個で すみ，さらにスーパーへテログイン方式などによっ て， B P F の中心周波数を高くすることもできる．も ちろん，中心周波数を高くすれば通過帯域を狭くする ことは困難になるが, メカニカルフィルタの発達によ って，通過帯域の狭い B P F の製作が容易になった。 そのかわり, 変調などの回路が必要となり, 回路構成 が複雜となるなどの短所があげられる.

（B）については，（A）の場合とまったく逆の立場に なる. 通過帯域が $1 / 3$ オクターブあるいは 1 オクター ブの B P Fを多数内蔵しているために, これら B P F 特性より，入力信号の振動数が低い所に扔いても高い 所においても，その分析能力は一定であり， B P F 自 体の設計は複雑であっても回路構成は簡単である。 た B P F を多数内蔵していることから，高価となるな どがあげられる.

低周波数の B P Fを, 通常のインダクタンス L, 容 量 $\mathrm{C}$ ，抵抗 $\mathrm{R}$ にって製作しようとすると，極度に值 の大きな LとC とが必要になり, 従来の方式, とくに （B）の方法によっては，低周波振動解析器は実用上製 作することができない.

そこで，この点を解決する方法として，ここでは， R，Cによる帯域消去形 Twin Bridge 回路を直流堌幅 器の帰還回路に入れることによってできる，いわゆ る, 能動フィルタを使用することにした。 この方法に より, 全体の構成としては（B)の方法を用い，能動 B P F の中心周波数は電話用セレクタスイッチを使用し て RとCとを切り換えることにより，1/12オクターブ ごとに順次移行するようにした。

このようにして, $1.00 \mathrm{H}_{\mathrm{z}}$ から $241.8 \mathrm{H}_{\mathrm{Z}}$ までの低周 波振動解析器を試作し, 実験してみた結果, 一応, 実 用の目安がついたので，ここに報告する.

\section{2. 帯域消去形 Twin Bridge 回路と BPF の特性}

図 1 亿帯域消去形 Twin Bridge 回路を示す. 図 1 の ように回路定数を決めると, 入力インピーダンス $Z_{s}$ $\simeq 0$, 出カインピーダンス $Z_{e} \simeq \infty$ のとき, この回路 の伝達関数 $G_{1}(S)$ はつぎのようになる. 


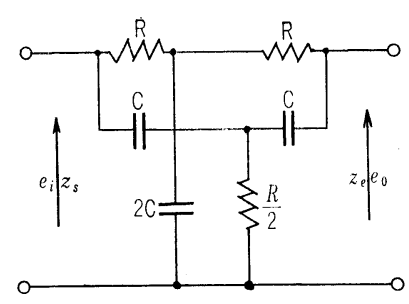

図 1 帯域消去形 RC Twin Bridge 回路

$G_{1}(S)=\frac{e_{0}}{e_{i}}(S)=\frac{S^{2}+1}{S^{2}+4 S+1}(S=j \omega C R)$

したがって，正弦波入力に対する定常解の振幅比 $G_{1}(\omega)$ は

$$
\begin{aligned}
& G_{1}(\omega)= \\
& 1-\frac{4 \omega / \omega_{0}}{\sqrt{\left\{1-\left(\omega / \omega_{0}\right)^{2}\right\}^{2}+\left(4 \omega / \omega_{0}\right)^{2}}}\left(\omega_{0}=\frac{1}{C R}\right) \cdots(2)
\end{aligned}
$$

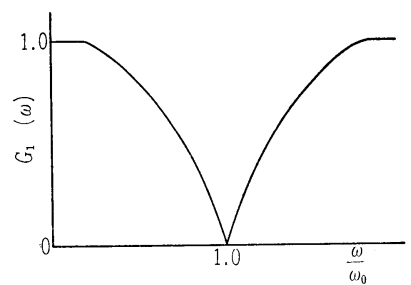

図 2 帯域消去形 Twin Bridge 回路の 周波数振幅特性

となる.これを $\omega / \omega$ 。 の関数として図に示せば, 図 2 のように左右対称となり，中心周波数では 鋭くとが る.

この Twin Bridge 回路で直流増幅器に負帰還を施 すことによって，B P F を製作することができる．羽 3 において, 増幅度 $\mu$ の直流増幅器に帰還量 $\beta$ を施す と, その入出力比 $e_{o} / e_{i}$ は

$$
\frac{e_{o}}{e_{i}}=\frac{\mu}{1+\beta \mu}
$$

となる. 式(3)において, 帰還量 $\beta$ の代わりに, 前に求 めた式(1)を代入すれば， B P F の特性を表わす伝達関 数が得られる。これを $G_{2}(\mathrm{~S})$ とすると，

$$
G_{2}(S)=\frac{\mu}{1+\mu} \frac{S^{2}+4 S+1}{S^{2}+4 S /(1+\mu)+1}
$$

となる

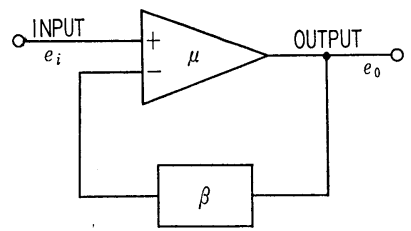

図 3 帰還増幅器
式(4)において, 正弦波入力に対する定常解の振幅比 $G_{2}(\omega)$ は

$$
\begin{aligned}
G_{2}(\omega)=\frac{\mu}{1+\mu}\left[1+\frac{4 \mu}{1+\mu}\right. & \left.\frac{\omega / \omega_{o}}{\sqrt{\left\{1-\left(\frac{\omega}{\omega_{o}}\right)^{2}\right\}^{2}+\left(\frac{4}{1+\mu} \frac{\omega}{\omega_{o}}\right)^{2}}}\right]
\end{aligned}
$$

となる。式(5)が B P F の周波数振幅特性を表わすもの でこれを図 4 に示す.

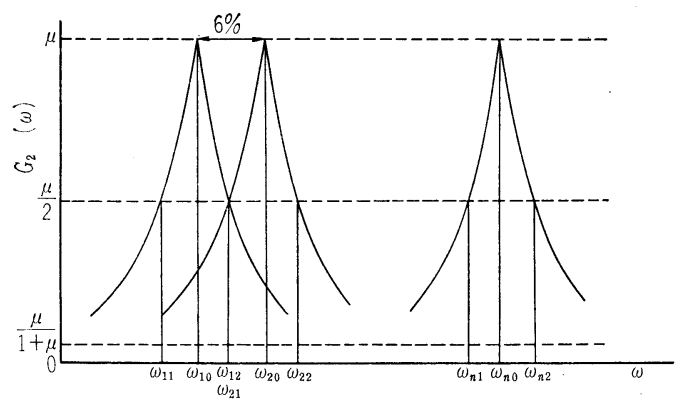

図 4 BPF の周波数振幅特性

本来なら（B）の方式のB P F の特性としては，通 過帯域が平たんとなることが望ましいが，図4 からわ かるように，このB P Fでは平たんとならず鋭くとが る. 通過帯域を平たんにするには，負性回路などを使 用することによって実現できるが，そのためには，非 常に精度の高い回路素子が数多く必要となるので, こ こでは図 4 に示す特性をもつ B P F をそのまま使用し た.

この B P F 1 オクターブ当たりなん個使用すれば よいかが問題となるが，本試作器においては12個／才 クターブとし，図 4 に示すように，一つのB P F とつ ぎに並ぶ B P F の特性曲線の交点が，その特性曲線の 最大值の半分，すなわち 般にはこの交点の值を70\%とするが，通過帯域をあま り広くすると B P F が鋭い周波数振幅特性をもてなく なるといらことと，1才クターブ当たりの B P F の数 をこれ以上多くすると，あまりに回路素子の数が多く なり切り換えて使用しにくいといら点を考慮して前述 のように決めた

ところで, この B P F の通過带域の幅は直流増幅器 の増幅度 $\mu$ にって決定されるのでこの $\mu$ を求める. 前述のように12個/オクターブのB P F が互いに $\mu / 2$ で交わるようにするための に, 一つのB P F の中心周波数を $\omega_{10}, \mu / 2$ となる周 波数をそれぞれ $\omega_{11}, \omega_{12}$ とすれば， $\omega_{11} / \omega_{10}, \omega_{12} / \omega_{10}$ はおのおの式(6)，(7)のよらになる。 
$\frac{\omega_{11}}{\omega_{10}}=\sqrt{1-\frac{8}{(1+\mu)^{2}}\left\{1-\frac{4 \mu^{2}}{(1-\mu)^{2}}\right\}-\frac{4}{1+\mu}}$

$\sqrt{\left\{1-\frac{4 \mu^{2}}{(1-\mu)^{2}}\right\}\left[-1+\frac{4}{(1+\mu)^{2}}\left\{1-\frac{4 \mu^{2}}{(1-\mu)^{2}}\right\}\right.}$

$$
\begin{aligned}
& \frac{\omega_{12}}{\omega_{10}}=\sqrt{1-\frac{8}{(1+\mu)^{2}}\left\{1-\frac{4 \mu^{2}}{(1-\mu)^{2}}\right\}} \\
&+\left.\left.\begin{array}{c}
4 \\
1+\mu
\end{array}\right) \sqrt{\left\{1-(1-\mu)^{2}\right.}\right\}[-1 \\
&\left.+(1+\mu)^{2}\left\{1-\frac{4 \mu^{2}}{(1-\mu)^{2}}\right\}\right]
\end{aligned}
$$$$
\text { ここで } \mu>>1 \text { とすれば，上.式は }
$$

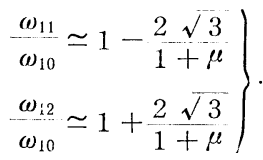

となる。

また，B P F の数を 12 個/オクターブとするために は，隣り合ったB P F の中心周波数の比は1.06となる 必要がある.これより, $\omega_{11} / \omega_{10} \simeq 0.97, \omega_{12} / \omega_{10} \simeq 1.03$ となり, $\mu \simeq 115$ を得る。

なお, 図 5 に B P F 用直流増幅器の回路図を示す.

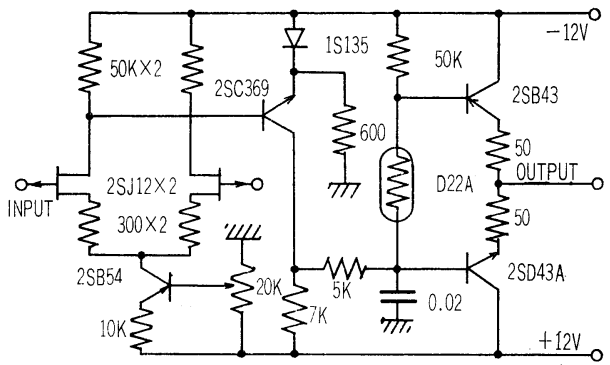

図 $5 \mathrm{BPF}$ 用直流増幅器の回路

\section{3. 試作した低周波振動解析器の回路構成}

奏際の回路を組み立てる場合，「win Bridge 回路 の R， Cの值は計算值と比較して誤差を伴う。とくに 容量 Cには漏れ抵抗があるので B P F の周波数振幅特 性は計算值のように鋭くとがることなく，頭の部分が 多少丸くなり, このため増幅器の増幅度は計算によっ て求めた值より多少大きく選ばなければならない。こ れは， R，C の精度に依存吉すのであるから，実験 的に求めなければ ならない。牛験に 上り, 角述の条件 を満足させるに必 要な増幅度は

$\mu=160$ となった 、実験により求め た B P F の周波 数振幅特性を図 6 に示す.

B P F の中心周 波数の移行は， 25 接点 4 回路（リレ -1 ) 5 接点 4 回 路 (リレー2)の 2 個の電話用セレ クタスイッチを用 いて行なら。すな わち，前者では抵 抗 $\mathrm{R}$ ，後者では 容量 Cを切り換え 1. $00 \mathrm{H}_{\mathrm{Z}}$ から 241.8 $\mathrm{H}_{\mathrm{Z}}$ まで $1 / 12$ オ

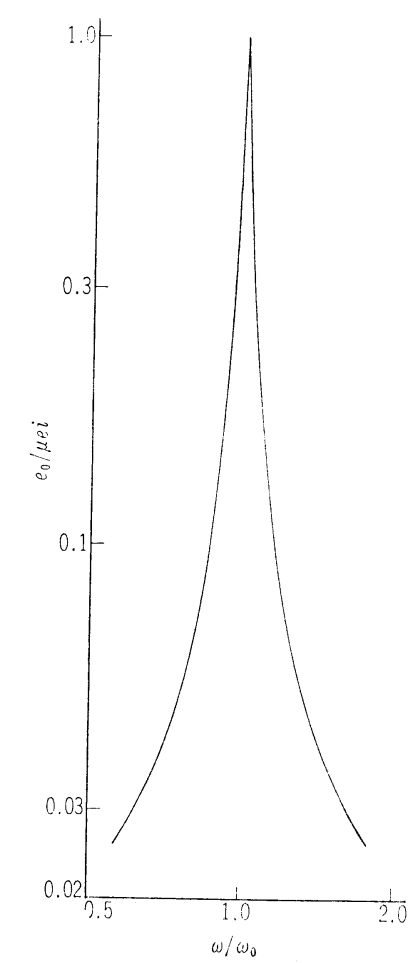

図 6 試作器 BPF の周波数振幅

\begin{tabular}{|c|c|c|c|c|c|c|c|c|c|c|c|}
\hline $\begin{array}{l}\mathrm{BPF} \text { の } \\
\text { 番 号 }\end{array}$ & $\begin{array}{l}\mathrm{BPF} \text { の中 } \\
\text { 心周波数 }\end{array}$ & $\begin{array}{c}\text { リレー } \\
\text { 端子番号 } \\
\text { リレー- } \\
-2-1\end{array}$ & $\begin{array}{l}\mathrm{BPF} の \\
\text { 番 号 }\end{array}$ & $\begin{array}{l}\mathrm{BPF} \text { の中 } \\
\text { 心周波数 }\end{array}$ & $\begin{array}{c}\text { リレー } \\
\text { 端子.番号 } \\
\text { リレー } \\
-2-2\end{array}$ & $\begin{array}{l}\mathrm{BPF} の \\
\text { 番 号 }\end{array}$ & $\begin{array}{l}\mathrm{BPF} \text { の中 } \\
\text { 心周波数 }\end{array}$ & $\begin{array}{c}\text { リレー } \\
\text { 端子番号 } \\
\text { リレー } \\
-2-3\end{array}$ & $\begin{array}{l}\mathrm{BPF} の \\
\text { 番 号 }\end{array}$ & $\begin{array}{l}\mathrm{BPF} \text { の中 } \\
\text { 心周波数 }\end{array}$ & $\begin{array}{c}\text { リレー } \\
\text { 端子番号 } \\
\text { リレー- } \\
-2-4\end{array}$ \\
\hline 1 & $\begin{array}{r}\mathrm{H}_{\mathrm{Z}} \\
1.00\end{array}$ & 1 & 25 & $\begin{array}{r}\mathrm{H}_{\mathrm{Z}} \\
4.00\end{array}$ & 1 & 49 & $\begin{array}{r}\mathrm{H}_{\mathrm{Z}} \\
16.00\end{array}$ & 1 & 73 & $\begin{array}{r}\mathrm{H}_{\mathrm{Z}} \\
64.0\end{array}$ & 1 \\
\hline 2 & 1.06 & 2 & 26 & 4. 24 & 2 & 50 & 16.96 & 2 & 74 & 67.8 & 2 \\
\hline 3 & 1.12 & 3 & 27 & 4. 48 & 3 & 51 & 17.92 & 3 & 75 & 71.7 & 3 \\
\hline 4 & 1. 19 & 4 & 28 & 4.76 & 4 & 52 & 19.04 & 4 & 76 & 76.2 & 4 \\
\hline 5 & 1.26 & 5 & 29 & 5.04 & 5 & 53 & 20.16 & 5 & 77 & 80.6 & 5 \\
\hline 6 & 1. 33 & 6 & 30 & 5.32 & 6 & 54 & 21.28 & 6 & 78 & 85.1 & 6 \\
\hline 7 & 1. 41 & 7 & 31 & 5.64 & 7 & 55 & 22.56 & 7 & 79 & 90.2 & 7 \\
\hline 8 & 1.50 & 8 & 32 & 6.00 & 8 & 56 & 24.00 & 8 & 80 & 96.0 & 8 \\
\hline 9 & 1.59 & 9 & 33 & 6.36 & 9 & 57 & 25.44 & 9 & 81 & 101.8 & 9 \\
\hline 10 & 1.68 & 10 & 34 & 6.72 & 10 & 58 & 26.88 & $1 J$ & 82 & 107.5 & 10 \\
\hline 11 & 1.78 & 11 & 35 & 7.12 & 11 & 59 & 28.48 & 11 & 83 & 113.9 & 11 \\
\hline
\end{tabular}
特性

表 1 リレー1，2 の端子番号と BPF の中心周波数との関係 
クターブごとに順次中心周波数を移行させる.

B P F の中心周波数とリレー1, リレー 2 の端子番 号との対応は表 1 に示すとおりである.

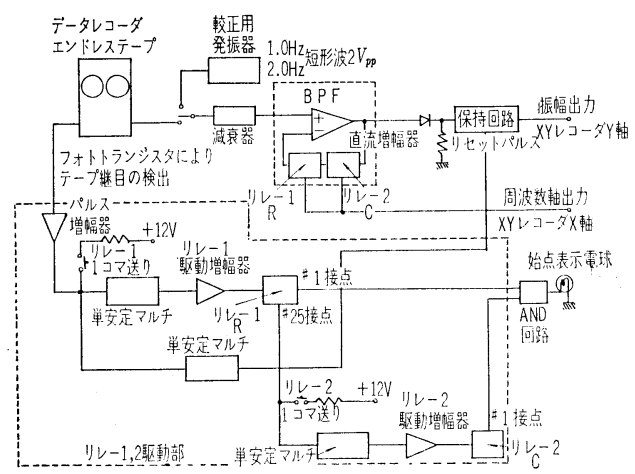

図 7 試作器のブロックダイアグラム

図 7 が試作器のブロックダイアグラムであり, 図 7 にしたがって，試作器の動作について説明する.

（イ）入力信号機関振動などを記録した磁気テ ープを約 $4 \mathrm{~m}$ (テープ速度7.5インチ/秒) 切り取り, 両端を継ぎ合わせ，エンドレステープとし，これを入 力信号とする。このとき，継目に約 $5 \mathrm{~mm}$ の間隙を取 っておきこの部分をフォト・トランジスタで検出し このパルスを B P F の中心周波数を移行させる制御信 号とする。

（口）周波数解析部（B P F） データレコーダ の出力は, 減衰器で解析につごうのよい電压にされ,

B P F にはいる. B P F の出力は整流され，保持回路 への入力となる。この保持回路は整流した後の電压の 最大值を保持するよらになっており，テープが一巡す ればそのときまで保持していた值はリセットされてゼ ロとなる。また，同時にリレー1の接点が 1 コマ移行
して B P F 6 中心周波数は表 1 に示すように $1 / 12$ オク ターブ高くなる.テープが一巡するたびに，この操作 がくり返えされる.

リレー1の接点が \#1の端子から 1 コマずつ移行し て\#25の端子までくると，この 秒の時間で井1の端子へ移行する. この時間中は B P F は動作しないようになっている。このときリレー 2 の 接点は 1 コマ移行し, Twin Bridge 回路の容量 Cの值 は,リレー 2 における前のCの值の $1 / 4$ となるように 定めてあり，これによって，リレー1の接点が一巡す れば， B P F の中心周波数は 2 オクターブ高くなる. そして, おのおのの中心周波数に対する出力電圧は, XYレコーダのY軸に振幅として記録される.

（八）周波数軸発生部 周波数軸の出力はリレー 1, リレー 2 の 4 番目の回路（ $1 \sim 3$ 番目の回路は,

Twin Bridge 回路の R,C を切り換えていくのに使用 している）を使用する.

リレー1の\#1〜 \#25 端子間にの $10 \Omega$ 抵抗を順次接続 し，また，リレー2の \#1〜\#4の端子間には $240 \Omega の$ 抵抗を順次接続してあり, リレー1の接点が 1 コマず

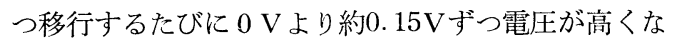
る.これをXYレコーダのX軸に周波数軸として記録 する.したがって, 周波数軸に通し番号を記載するこ とによって, 表 1 の P F の番号からその周波数に対 する出力がわかる。

（ニ）リレー1, リレー 2 駆動部 データレコー ダのテープの継目をフォト・トランジスタで検出し,

これをパルス増幅器で増幅し, このパルスでリレー 1 の接点を 1 コマずつ移行させる。このときリレー 1 の 作動時間が約 0.1 秒のために, フォト・トランジスタ からのパルス時間では短かすぎて作動しないために単 安定マルチを使用してパルス幅を 0.1 秒にのばサ. \#25

\begin{tabular}{lll||rrr||rrr||lll}
\hline 12 & 1.89 & 12 & 36 & 7.56 & 12 & 60 & 30.24 & 12 & 84 & 121.0 & 12 \\
13 & 2.00 & 13 & 37 & 8.00 & 13 & 61 & 32.00 & 13 & 85 & 128.0 & 13 \\
14 & 2.12 & 14 & 38 & 8.48 & 14 & 62 & 33.92 & 14 & 86 & 135.7 & 14 \\
15 & 2.24 & 15 & 39 & 8.96 & 15 & 63 & 35.84 & 15 & 87 & 143.4 & 15 \\
16 & 2.38 & 16 & 40 & 9.52 & 16 & 64 & 38.04 & 16 & 88 & 152.3 & 16 \\
17 & 2.52 & 17 & 41 & 10.08 & 17 & 65 & 40.32 & 17 & 89 & 161.3 & 17 \\
18 & 2.67 & 18 & 42 & 10.68 & 18 & 66 & 42.72 & 18 & 90 & 170.9 & 18 \\
19 & 2.83 & 19 & 43 & 11.32 & 19 & 67 & 45.28 & 19 & 91 & 181.1 & 19 \\
20 & 3.00 & 20 & 44 & 12.00 & 20 & 68 & 48.00 & 20 & 92 & 192.0 & 20 \\
21 & 3.17 & 21 & 45 & 12.68 & 21 & 69 & 50.72 & 21 & 93 & 202.9 & 21 \\
22 & 3.36 & 22 & 46 & 13.44 & 22 & 70 & 53.76 & 22 & 94 & 215.0 & 22 \\
23 & 3.56 & 23 & 47 & 14.24 & 23 & 71 & 56.96 & 23 & 95 & 227.8 & 23 \\
24 & 3.78 & 24 & 48 & 15.12 & 24 & 72 & 60.48 & 24 & 96 & 241.8 & 24 \\
\hline
\end{tabular}


の端子には+12Vの電圧が印加されており,リレー の接点が\#25の端子にセットされたときに，この電圧 を增幅してリレー 2 を作動させる.このリレー 2 の接 点が1コマ移行することによって, B P F の中心周波数 は 4 倍となる。 またリレー 1 の接点が \#25 の端子にセ ットされているとき，この電圧が周波数軸出力に混入 するのを防ぐため, 約 0.2 秒の時間で\#1の端子へ移行 寸る回路が必要である(図7には省略してある).

解析を始めるとき，リレー1の接点が\#1の端子に， リレー2の接点が井の端子にあることが必要である.

これを指示するために, リレー1, リレー2の接点が それぞれの \#1 端子にあるとき始点表示の電球が点灯 するようになっている.この電球が点灯しているとき には，B P F の中心周波数が $1.00 \mathrm{H}_{\mathrm{Z}}$ にあることを 示す.

また, リレー1, リレー 2 の接点を 1 コマずつ手動 で作動できるように押しボタンを付けてある.

（ホ）較正回路 較正回路として，周 波数 1.00 $\mathrm{H}_{\mathrm{Z}}$ または $2.00 \mathrm{H}_{\mathrm{Z}}$, 出力電圧 $2.0 \mathrm{~V}_{\mathrm{P}-\mathrm{P}}$ の矩形波発振 器を内蔵している。 この矩形波を試作器の入力として 周波数分析し, その出力を用いて, XYレコーダのY 軸, 寸なわち, おのおのの周波数成分の出力の值と比 較較正する.

なお， B P F の通過帯域は非常に狭いため， B P F の出力が定常值に達するまでに約 20 波数は必要であ り， $1 \mathrm{H}_{\mathrm{z}}$ 近傍の周波数成分を解析するためには約 20 秒 を要する. したがって, テープ速度7.5インチ/秒のデ ータレコーダを使用するものとすれば， $3.8 \mathrm{~m}$ 以上上の エンドレステープが必要となる。

\section{4. 実 験 結 果}

試作器の性能を調べるために, 既知の入力波形を使 用して, これを試作器によって解析してみた。 また参 考のため, この入力波形をペンオシログラフに描か せ, これを読み取り, デイジタル計算機によってフー リエ解析したものとも比較してみた。

入力信号は 6 台の低周波発振器を用いて, これをア ナログ計算機用加算器で合成したもので, このときの 周波数および各発振器の出力電圧の比率を表 2 亿示

表 2 基本波 $(2.0 \mathrm{~Hz})$ 飞対する各高調波成分の 振幅比

\begin{tabular}{lc|c|c|c|c|c|c}
\hline \hline 周 波 数 $\mathrm{Hz}$ & 2.00 & 4.00 & 6.00 & 10.0 & 14.0 & 20.0 \\
入 力 信 号 & 1.00 & 0.50 & 0.75 & 1.50 & 1.00 & 1.00 \\
試作器の解析出 & 1.00 & 0.58 & 0.83 & 1.60 & 0.96 & 0.70 \\
力 \\
数值計算による \\
解析
\end{tabular}

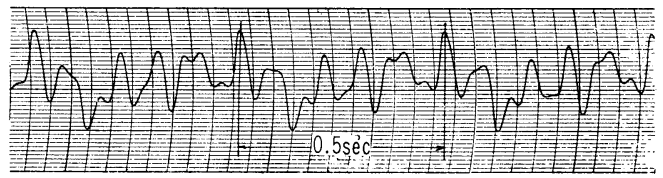

眓 8 入力信号の合成波形

寸，図 8 がその合成波形である。なお，フーリ工解析 を行なった結果については，一周期を50等分し，20番 目までの高調波成分について求めた。

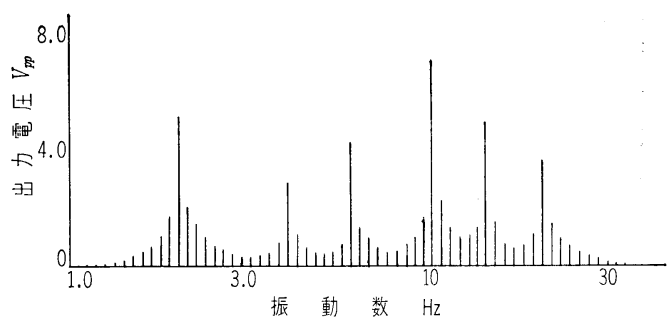

図 9 試作器による解析出力の (BPF 出力)

図 9 は表 2 の入力信号を試作器で解析した結果を示 す. 図 9 は保持回路にはいる前の電圧をペンオシログ ラフに描かせて，そのときの出力振幅を読み取ったも のである。これは B P F 自体の精度を調べるために, 保持回路以前の出力を記載した。

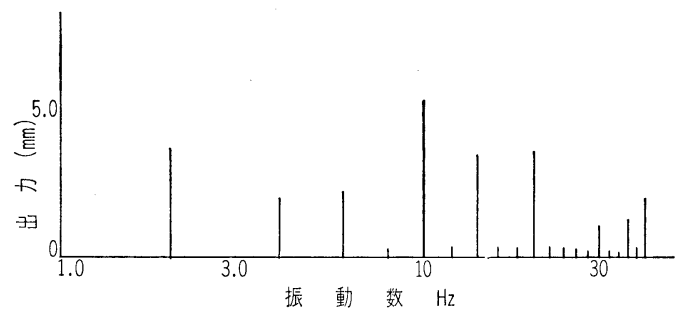

四10 数值計算による解析結果

図10に数值計算によってフーリエ解析した結果を示 す. 数值計算による解析では, 実際には含まれていな い高調波成分がかなり出てくることがわかる。これは 読み取りにおける誤差が高調波成分として出てくるた めと思われる. また, 試作器では振動数成分は一応正 しく解析している，また，振幅については，各成分の 比率もだいたい出ているが，数值計算によるもののほ うがややよい.

図 8 の入力信号を試作器で解析し, 保持回路を経由 した後の出力をXYレコーダに記録したものを図11に 示す. 図11において，全周波数が表 2 と比較して 2 倍 となっているのは, 解析時間を短縮するために, デー タレコーダのテープ速度を記録時の 2 倍の速度で再生 したためである、したがって, 実際の入力信号の周波 数は図11の B P F の中心周波数の半分となる. 
なお，任意の振動数，振幅を合成したものにつけて の解析結果の数例を図12〜図14に示寸.

図12に $1.5 \mathrm{H}_{\mathrm{Z}}$ の矩形波を解析した結果を示寸。矩形 波には，1．3．5.…と奇数次高調波成分が含まれ，
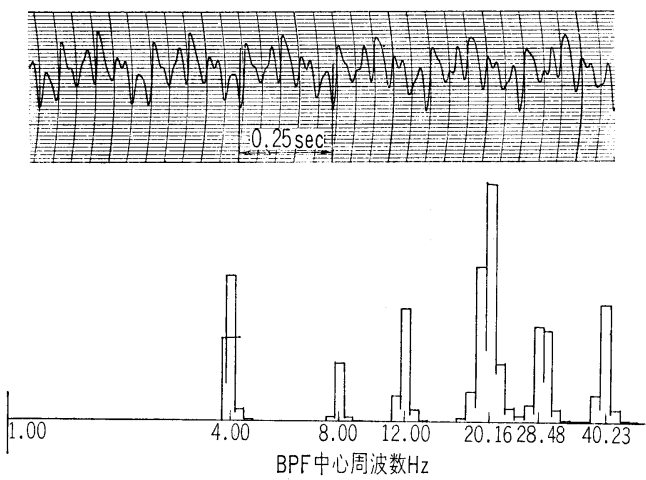

図11図 8 の合成波形の解析絬果
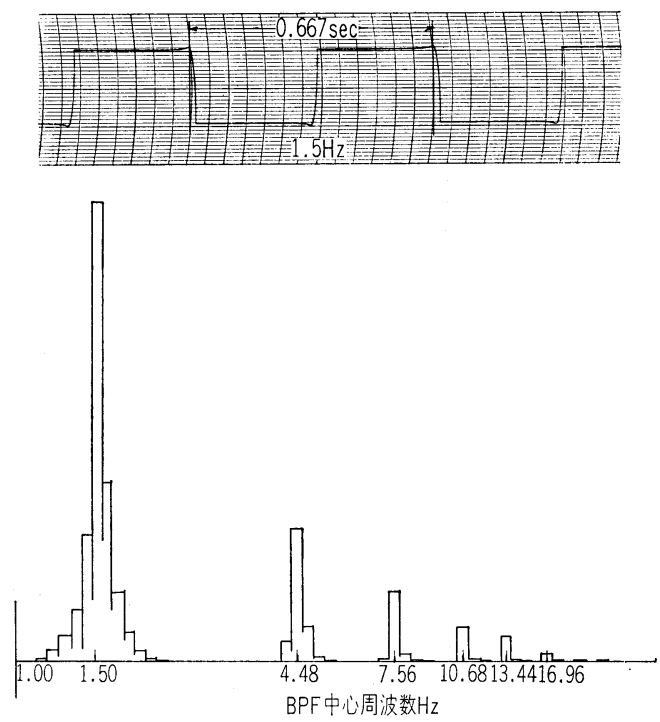

図12 解析例 1 入力信号 $1.5 \mathrm{H}_{\mathrm{z}}$ 矩形波
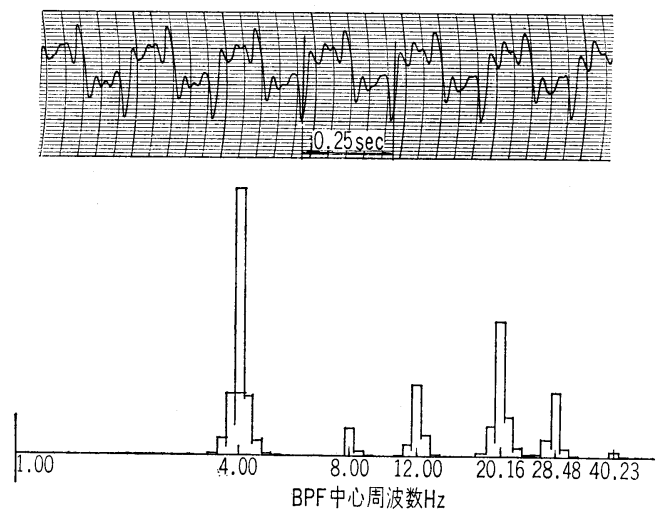

図13 解析例 2 入力信号 $4 ， 8 ， 12 ， 20 ， 30 ， 40$, $\mathrm{H}_{\mathrm{z}}$ 正弦波の合成波形
図12に示されているように，第11次高調波まで判別で きた。

図 13 は, $4.00 \mathrm{H}_{\mathrm{z}}, 8.00 \mathrm{H}_{\mathrm{z}}, 12.0 \mathrm{H}_{\mathrm{Z}}, 20.0 \mathrm{H}_{\mathrm{z}}$, $30.0 \mathrm{H}_{\mathrm{Z}}, 40.0 \mathrm{H}_{\mathrm{Z}}$ の正弦波の合成波形を解析したもの である。これらの各周波数成分の振幅は任意に選んた 図14は, $4.00 \mathrm{H}_{\mathrm{z}}, 8.00 \mathrm{H}_{\mathrm{Z}}, 12.0 \mathrm{H}_{\mathrm{z}}, 20.0 \mathrm{H}_{\mathrm{z}}$ の正 弦波の合成波形を解析したものである.

図12〜14において，入力信号の周波数之解析出力の 周波数とが多少一致しないところがあるが，これは試 作器の B P F の中心周波数が1/12オクターブごとに階 段状に変化するため生じたものである.
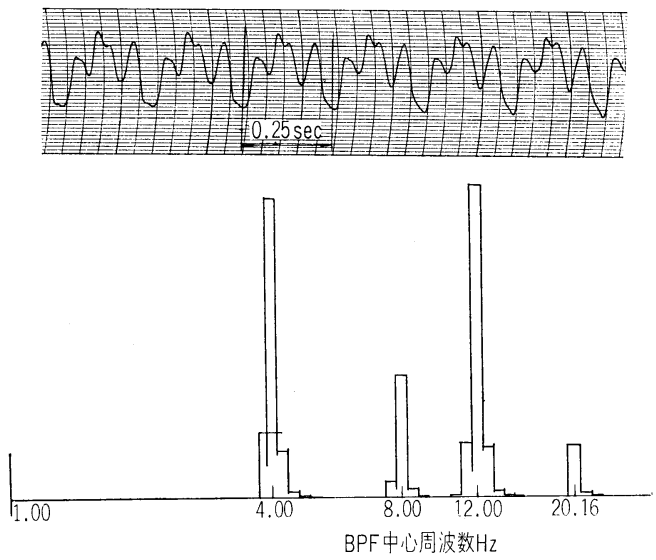

図14 解析例 3 入力信号 $4,8,12,20, \mathrm{H}_{\mathrm{z}}$ 正弦波 の合成波形

\section{5. 結言}

RC Twin Bridge 回路による能動フィルタを用い て, 低周波振動解析器を試作し, あらかじめ振動数と 振幅のわかっている信号を入力として, 本試作器で解 析してみた。 また，この信号をペンオシログラフに描 かせ，その一周期を読み取り，計算機でフーリエ解析 したものとも比較してみた。その結果つぎのことがわ かった。

（1）本試作器は振動数成分については一応正しく 解析している.

（2）振幅については，各成分の比率もほぼ正しく 示されているが，計算機でフーリエ解析を行なったも ののほうがややよい

（3）しかし, 計算機で求めたものについては,読み 取り誤差により，高次において大きな誤差が現われる.

以上のような結果から判断して, 能動フィルタ方式 による低周波振動解析器の実用化の見込みが十分ある と考えられる。

\section{文献}

(1) Harry F. Olson Acoustical Engineering [西巻訳 : 音響工学上下卷] 